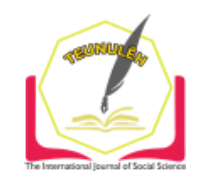

Jurnal Ilmiah Teunuleh

The International Journal of Social Sciences

Vol. 2, Issue. 2, June 2021

E-ISSN: 2746-4393

\title{
CAPITAL MARKET REACTION BEFORE AND AFTER THE ANNOUNCEMENT OF THE FIRST CASE OF COVID-19 IN INDONESIA
}

\author{
Sarlina Sari \\ Universitas Bina Sarana Informatika
}

\begin{abstract}
This study aims to determine the differences in abnormal return, frequency of trade, and market capitalization before and after the informations regarding the first reporting of COVID-19 in Indonesia on the Indonesia Stock Exchange. The research population is all companies that entered into Top Leadings in Market Capitalization companies on the Stock Exchange in the period Februari-April 2020, namely as many as 50 companies. The sample in this study was taken using the census method, meaning that the number of samples taken was equal to the number of members of the population. To test the hypothesis of this study using a paired sample test. The observation began 30 days before the event and 30 days after the event. This study uses quantitative research in the comparative method. The finding show that the information caused the market was approved. This is proven by the existence of significant results in daily tests on the indicators. The results were also significant in the combined abnormal return test and the combined market capitalization test. The trade comparison test results show a significant difference which means there was a market-panic towards trading activities after the event that caused some frequency differences, before and after the event in terms of trade transactions. So, the results of this study indicate that there are differences in abnormal returns, frequency of trade, and market capitalization before and after the announcement of the informations regarding the first reporting of COVID-19 in Indonesia.
\end{abstract}

Keywords: Capital Market Reaction, Frequency of Trade, Covid-19 in Indonesia

\section{A. Introduction}

The Corona virus, known as Covid-19, which was present and hit the world in 2020, is a nightmare for countries in the world. The impact is not only affecting the health of the world's population, but also for the country's economy. The corona virus pandemic (COVID-19) is putting heavy pressure on the economy in Indonesia and is a nightmare that has become a reality for the Indonesian currency. When the Indonesian government 
announced the first Covid-19 patient, the rupiah was under intense pressure. As a result of the pandemic, many countries implemented regional quarantine (lockdown) policies to reduce its spread. As a result, economic activity has decreased sharply, and the recession has returned (Inri B. Sambuari, Ivonne S. Saerang, 2020).

Covid-19 or Corona Virus Disease is a new virus that attacks the human respiratory system, after it was first discovered in Wuhan, China at the end of 2019, quickly spreading throughout the world. This virus instantly made it a pandemic in more than 200 countries in the world. The impact is not only on the health sector but has an effect on various aspects of life and has a major impact on world economic traffic such as China, the US, Japan, Korea, leading to a world recession. IMF (International Monetary Fund) states that the current condition is entering an economic crisis with a situation that is more severe than 2008 which not only has an impact on the Money Market but also has a significant impact on the Capital Market. The stock price index all over the world dropped drastically as well as the $\mathrm{JCl}$ in Indonesia had dropped sharply and touched its lowest level at Rp. 3,911.71. To keep market conditions from continuing to decline, the OJK (Financial Services Authority) and the Indonesia Stock Exchange issued several policies such as reducing 1.5 hours of exchange trading from normal trading hours in effect from March 30, 2020, OJK also gave issuers the flexibility to make repurchases. (buyback) shares without asking for prior approval at the General Meeting of Shareholders, Implementing a policy of temporarily stopping trading for 30 minutes if there is a decrease of $5 \%$ in intraday trading (Putri, 2020). So, the Corona Virus is certain to have an impact on the Indonesian economic sector, where the capital outflow or capital outflow in the stock market also occurs as much as Rp. 980 billion.

The event to be tested for its information content on the capital market is the Corona Virus event in Indonesia. Testing the information content of market activity is intended to see the market reaction to these events. If it contains strong information, there will be a reaction received by the market. The reaction to this Corona Virus event is measured using abnormal returns as the value of price changes, and to ascertain whether there is an effect of information on the Corona Virus event that occurred in Indonesia. With the occurrence of abnormal returns, it can be said that an event announcement that contains information will give an abnormal return to the market (Inri B. Sambuari, Ivonne S. Saerang, 2020).

The frequency of stock trading is the total sale and purchase of industrial shares at a certain time or period (Shabib-ul-hasan, Syed, Sumair Farooq, 2015). An increase in 
demand for shares will increase the frequency of trading. The increase in the frequency of trading transactions will encourage stock prices to increase so that stock returns will also increase. The information content is also able to affect the value of stock trading. According to Taslim and Wijayanto (2016) market capitalization is the multiplication of the closing price on the market and the total issued shares. So that the conclusion obtained states that market capitalization is the value of the size of a share that has been issued by the industrial owner. Investors are usually eyeing a stock that has a high capitalization so that it can be used as a measure in carrying out a fairly long-term investment due to the extraordinary development of the industry which is balanced with profit sharing and low risk exposure. Due to the high demand, the stock price is usually relatively large so that it will share a large return as well. To see whether an event contains abnormalities or not, event study method research is used. Event study is research by studying the market reaction to an event whose information is published as an announcement by taking a sample in the form of closing stock prices (Niawaradila et al., 2021).

The choice of the manufacturing industry in this study is because it is related to the basic needs needed by humans to survive, so the shares of the company are still able to make a profit even though economic conditions are deteriorating. For this reason, it can be seen whether the manufacturing industry is able to survive in an unstable state due to the Corona Virus incident.

\section{B. LITERATURE REVIEW}

\section{Corona Virus}

At the end of 2019, the world was shocked by the emergence of a new virus called the 2019 Novel Coronavirus (2019-nCoV) which is better known as the Corona Virus which first appeared in Wuhan City, China. Coronavirus is a collection of viruses that can infect the respiratory system and can be transmitted from human to human. The Corona virus is reported to have occurred in more than half of the countries in the world. More than 113,000 people have been infected with the Corona Virus, and more than 4,000 people have died due to the COVID-19 disease. In Indonesia, the first case of the Corona Virus occurred in early March. This was conveyed by Indonesian President Joko Widodo in his speech at the Presidential Palace, Jakarta on March 2, 2020. Jokowi said that two people who tested positive for the Corona Virus were infected from Japanese citizens who came to Indonesia. International media also released news regarding the 
confirmation. The Ministry of Health determined the Corona Virus case as an Extraordinary Event (KLB) on March 3, 2020. The emergence of the Corona Virus made all aspects of the "Bamboo Curtain" country completely paralyzed. The country's economy is also disrupted, and has an impact on other countries in the Southeast Asia Region, even globally. As a result of this virus, many foreign investors sold their shares due to the panic that the capital market abroad experienced a drastic decline. Asian exchanges also reacted to this incident. Not only in the Asian region, the United States and Europe have also experienced a decline. The Asian Development Bank (ADB) estimates that the Corona Virus outbreak will cause global economic losses of US \$347 billion or the equivalent of Rp. 4,944 trillion (Akbar, 2019).

\section{Stock Trading}

The financial market is a market where there is a meeting between those who have excess funds and those who are short of funds. In this market, there will be a transaction, in which the party that lacks funds will get funds from the party that has excess funds. In general, financial markets are divided into two, namely direct and indirect (Hanafi, 2008: 61-63). The financial market does not directly use intermediary instruments such as banks. The direct financial market is dominated by the capital market. There are two types of instruments contained in the capital market, namely debt instruments and equity instruments or the stock market (Deasy Lestary Kusnandar and Vivi Indah Bintari, 2020).

\section{Trading Frequency}

The frequency of stock trading is the number of share trading transactions in a certain period (Silviyani, 2014 in (Taslim Ahmad, 2016)). Frequency describes the number of times an issuer's shares have been traded in a certain period of time. If a stock has a high frequency, it is predicted to have active trading activity, this is due to the large amount of investor attention, so it can be recognized that the stock investors want or not. According to research (Andiani, Ni Wayan Sekar, 2018), formulating if trading frequency has a significant positive effect on stock returns. The same research was tried (Taslim Ahmad, 2016), which formulated trading frequency to have a significant positive effect on stock returns. Research tried by (Taslim Ahmad, 2016) aims to obtain empirical facts that there is a significant effect of trading frequency on stock returns.

\section{Market Capitalization}

Market capitalization or market capitalization is the market value of the shares issued by an issuer. A large market capitalization is generally one of the attractions of 
investors in choosing stocks. Investors are usually eyeing a stock that has a high capitalization so that it can be used as a measure in carrying out a fairly long-term investment due to the extraordinary development of the industry which is balanced with profit sharing and low risk exposure. Due to the high interest, the stock price is usually relatively large so that it will share a large return (Hanafi, 2008).

\section{Stock Returns}

According to (Hartono, 2003) stocks are divided into two, namely realized return is the return that has occurred and expected return is the return expected by investors in the future. Based on the notion of return, that the return of a stock is the result obtained from investment by calculating the difference between the current period's stock price and the previous period by ignoring dividends, then the formula can be written (Ross, S. A., Westerfield, R., \& Jordan, 2003):

$$
R_{t}=\frac{P_{t}-P_{t-1}}{P_{t-1}}
$$

Keterangan: $\quad \mathrm{Rt}=$ Return saham pada periode ke-t

$\mathrm{Pt}=$ Harga saham periode pengamatan

Pt-1 = Harga saham periode sebelum pengamatan

\section{Abnormal Return}

Abnormal return is the difference between the actual return and the expected return. Abnormal returns are often used to evaluate the performance of securities. Abnormal returns can also be used as a basis for testing market efficiency. The market will be said to be efficient if none of the market players enjoy the abnormal return in a long enough period of time. Apart from the abnormal return, there is also a CAR (Cumulative Abnormal Return). CAR is the sum of all levels of profit that are not normal. CAR is also usually calculated to include abnormal returns with a small span, only a few days. The reason is, compounding returns to normal after giving clear results. CAR is the sum of the previous day's abnormal returns in the event period for each security. Abnormal returns usually occur around the announcement of an event. These events include, for example, mergers and acquisitions, dividend announcements, announcements of productive companies, lawsuits, increases in interest rates and others. The phenomenon of abnormal returns also often occurs when the market closes (market on close) of the IDX. This abnormal return arises due to a significant increase in trading activity. All activities in the financial sector can usually be interpreted as 
information or events that can affect the previous or subsequent prices on the financial market (Deasy Lestary Kusnandar and Vivi Indah Bintari, 2020).

\section{Research Hypothesis}

Based on the background previously described, the research hypothesis is:

$\mathrm{H} 1$ : There is a difference in abnormal returns in the period before and after the announcement of the first case of Corona Virus (COVID-19) in Indonesia in manufacturing companies listed on the Indonesia Stock Exchange.

$\mathrm{H} 2$ : There is a difference in trading frequency in the period before and after the announcement of the first case of Corona Virus (COVID-19) in Indonesia in manufacturing companies listed on the Indonesia Stock Exchange.

H3: There is a difference in market capitalization in the period before and after the announcement of the first case of Corona Virus (COVID-19) in Indonesia in manufacturing companies listed on the Indonesia Stock Exchange.

\section{Event Study}

The event study is a form of empirical testing to determine the efficiency of the semi-strong form by seeing how quickly prices adjust to new information. Several stages in conducting an event study, namely (Rahyuda, 2004):

a. Identify certain events (events) and their date.

b. Determine the time span of the event study (event window) which is the time to be observed around the event. Besides that, the estimation period is also determined which will be used to forecast the expected return in the event period.

c. Calculating the abnormal return during the event window, then performing a statistical test on the abnormal return

\section{RESEARCH METHODS}

This study uses an event study to analyze the movement of abnormal returns that occur from day to day with an event period of 30 days. The timing in this study is the date of issuance of the announcement of the change in trading time on stock exchange transactions, namely March 26, 2020 as $t=0$. The event window period is divided into two, consisting of the first $t=-30$ (30 days before the announcement of the change in trading time for exchange transactions) and the second $t=30$ (30 days after the announcement of the change in trading time for exchange transactions). The determination of the event window period is based on previous studies and to avoid confounding effects or information mixing. The object of this research is abnormal 
return. To calculate the abnormal return, you must first look for the actual return and the expected return. To calculate the expected return, use the Market Adjusted Model measurement, because it makes it easier to detect abnormal returns. The Market Adjusted Model has considerable potential to produce a strong statistical test compared to other statistical models, namely the adjusted mean and the market model.

The study population was all companies that entered into the top 50 leadings in market capitalization companies on the IDX in the period February - April 2020, as many as 50 companies. The sample in this study was taken using the census method, meaning that the number of samples taken was the same as the number of members of the population (Sugiyono, 2014). To test the hypothesis of this study using Paired sample test. This test is used to determine whether or not there is an average difference between two paired (related) sample groups. That is, a sample but under two different treatments.

\section{Data and Sources}

Data The type of data used is ratio data which has absolute zero value. The data source used is secondary data, which is obtained through the website www.idx.co.id to collect the daily stock price (clossing price), the number of daily stock trading transactions (frequency), and the value of stock trading (market capitalization).

\section{Collection Data Technique}

Data Collecting and studying books, literature, journals, and theories related to this research. Documentation is used to obtain daily stock trading data.

\section{Operational Definition of Variables}

a. Abnormal Return

The simplest way to calculate abnormal returns is to calculate the difference between actual returns and expected returns, using the formula (Deasy Lestary Kusnandar and Vivi Indah Bintari, 2020):

$$
\text { RTNi.t }=\text { Ri.t }-E[\text { Ri.t }]
$$

Where:

RTNi.t is the abnormal return for stock $i$ on event $t$ (or on day $t$ )

Ri.t is the actual return on stock $i$ that occurs on day $t$

$E[R i . t]$ is the expected return for stock $i$ on day $t$

b. Trading Frequency

$$
\sum \text { frekuensi }=\frac{\text { Jumlah frekuensi saham }}{\text { Hari pengamatan }}
$$


c. Market Capitalization

$$
\mathrm{Vs}=\mathrm{Ps} \times \mathrm{Ss}
$$

Information:

Vs = Market capitalization

$\mathrm{Ps}=$ Market price

Ss $=$ Number of shares issued

\section{Result and Discussion}

\section{Hypothesis Test Results}

Normality Test

\begin{tabular}{|c|c|c|c|c|c|c|c|}
\hline & & $\begin{array}{l}\text { Abnormal } \\
\text { Return } \\
\text { Before }\end{array}$ & $\begin{array}{c}\text { Abnormal } \\
\text { Return After }\end{array}$ & $\begin{array}{l}\text { Frequency } \\
\text { Before }\end{array}$ & $\begin{array}{l}\text { "requency } \\
\text { After }\end{array}$ & $\begin{array}{c}\text { Market } \\
\text { Capitalization } \\
\text { Before }\end{array}$ & $\begin{array}{c}\text { Market } \\
\text { Capitalization } \\
\text { After }\end{array}$ \\
\hline \multirow[t]{2}{*}{ N } & & 50 & 50 & 50 & 50 & 50 & 50 \\
\hline & Mean &,- 0183 & 0093 & 413,1273 & 648,5606 & 6972036609,6 & 8246347511,2 \\
\hline Normal & & & & & & 970 & 121 \\
\hline Parameters $\mathrm{a}, \mathrm{b}$ & $\begin{array}{l}\text { Std. } \\
\text { Deviation }\end{array}$ & ,87251 & 10552 & 1015,00427 & 1656,71070 & $\begin{array}{r}23950317899 \\
09209\end{array}$ & $\begin{array}{r}23995100839 \\
41866\end{array}$ \\
\hline Most Extreme & Absolute & ,431 & 209 & ,342 & ,348 & ,385 & ,385 \\
\hline \multirow[t]{2}{*}{ Differences } & Positive & ,380 & 209 & ,334 & ,332 & ,364 & ,385 \\
\hline & Negative &,- 431 &,- 158 &,- 342 &,- 348 &,- 385 &,- 366 \\
\hline \multicolumn{2}{|c|}{ Kolmogorov-Smirnov Z } & 11,075 & 5,360 & 8,786 & 8,933 & 9,903 & 9,880 \\
\hline \multicolumn{2}{|c|}{ Asymp. Sig. (2-tailed) } & ,120 & ,450 & 110 & ,230 & ,320 & 200 \\
\hline
\end{tabular}

Source: Data processed 2020

Asymp Value. Sig (2-tailed) of abnormal return, trading frequency, and market capitalization before and after the event obtained a test value above 0.05. So it can be concluded that the data is normally distributed because of Sig. > alpha. The results of this test are used as the basis for testing the hypothesis using the paired sample t-test.

\section{Combined Paired Sample Test}

\begin{tabular}{|c|c|c|c|c|c|c|c|c|}
\hline \multicolumn{2}{|c|}{ Paired Differences } & \multirow{3}{*}{ Mean } & \multirow{3}{*}{$\begin{array}{c}\text { Std. } \\
\text { Deviation }\end{array}$} & \multirow{3}{*}{$\begin{array}{l}\text { Std. } \\
\text { Error } \\
\text { Mean }\end{array}$} & & \multirow[t]{3}{*}{$\mathrm{t}$} & \multirow[t]{3}{*}{ df } & \multirow{3}{*}{$\begin{array}{l}\text { Sig. (2- } \\
\text { tailed) }\end{array}$} \\
\hline & & & & & $\begin{array}{l}\text { 95\% Confidence Interval of } \\
\text { the } \\
\text { Difference }\end{array}$ & & & \\
\hline & & & & & Upper & & & \\
\hline $\begin{array}{c}\text { Pair } \\
1\end{array}$ & $\begin{array}{l}\text { Abnormal Return } \\
\text { Before - Abnormal } \\
\text { Return After }\end{array}$ &,- 02768 & ,86468 & ,03366 & $-, 09377 \quad, 03841$ &,- 822 & 659 & 411 \\
\hline
\end{tabular}


Capital Market Reaction Before and After Announcement of the First Case of COVID-19...

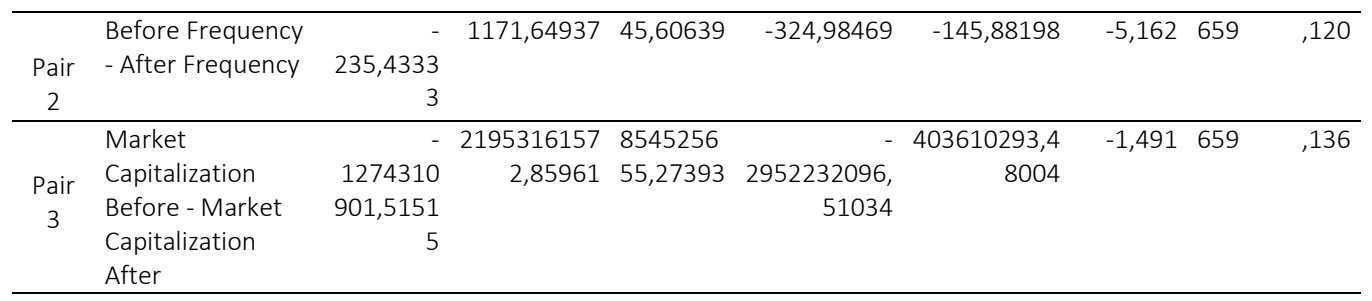

Source: Data processed 2020

The result of the combined abnormal return difference test is $0.411>\operatorname{Sig}$ (2-tailed). The result of the combined trade frequency difference test is $0.120>$ Sig (2-tailed). The result of the combined market capitalization difference test is $0.136>\operatorname{Sig}$ (2-tailed). This shows that the abnormal return hypothesis, trading frequency and market capitalization are accepted, meaning that there are differences in abnormal returns, trading frequency and market capitalization before and after the announcement of the first case of Corona Virus (COVID-19) in Indonesia.

\section{Discussion}

\section{a. Hypothesis I}

There are differences in abnormal returns before and after the announcement of the first case of Corona Virus (COVID-19) in Indonesia, both from combined test results and partial daily test results (before vs after), it can be seen that this event contains information so that there is a reaction arise and have a major influence on market players on activities in the capital market, especially in the manufacturing sector This happened due to the sudden announcement made by the President of Indonesia on March 2, 2020, even though other countries in Southeast Asia had announced the first cases of the Corona Virus before this event occurred in Indonesia. This means that the information obtained by investors tends to be massive, so that investors must immediately run to secure their investment by investing it in other safer assets such as precious metals. For this reason, stock exchange activities tend to be characterized by buy and sell action after the announcement, and investors are rushed in making decisions, so that these events affect returns that are not normal for investors.

\section{b. Hypothesis II}

There is a difference in trading frequency before and after the announcement of the first case of Corona Virus (COVID-19) in Indonesia in a joint test indicating this information is bad news for investors, due to sentiment that causes panic investors after the increasing number of positive victims of Corona panic selling. As a result, foreign 
investor funds in the domestic stock market continue to experience withdrawals towards gold investment when the stock market is faltering. This can be seen from the increase in global gold prices followed by Antam's precious metal which jumped $12.14 \%$. However, the results of the daily test partially (before vs after) showed insignificant results. This means that this event has an impact on stock trading activities but on a daily basis the fluctuation is small, so that almost no reaction occurs, even though there is actually a reaction.

The difference in stock trading frequency is not proportional to the difference in abnormal returns. After the continuous panic, the OJK immediately issued a buyback policy without the first AGM, to overcome the decline in the $\mathrm{JCl}$ and reduce the risk of a lower autoreject. As a result, even though the trading frequency is quite high after the event, it does not make investors get an abnormal return. This means an increase in the frequency of trading transactions, not always followed by an increase in stock returns.

\section{c. Hypothesis III}

There is a difference in market capitalization before and after the announcement of the first case of Corona Virus (COVID-19) in Indonesia, both from combined test results and partial daily test results (before vs after), it can be said that this event contains information for investors and traders. influencing investment decision making, but investors still see investment opportunities in stocks in food and beverage companies, and companies are still able to earn profits (although not high) because considering food and beverages are basic daily necessities that are still needed despite the outbreak. Corona virus.

\section{E. Conclusion and Suggestions}

\section{Conclusion}

1. The announcement of the first case of Corona Virus (COVID-19) in Indonesia at a manufacturing company listed on the Indonesia Stock Exchange, contains information that causes the capital market to react to abnormal returns in terms of investment returns.

2. The announcement of the first case of Corona Virus (COVID-19) in Indonesia at a food and beverage company listed on the Indonesia Stock Exchange, contains information that causes the capital market to react to trading frequency in terms of trading transaction activities. 
Capital Market Reaction Before and After Announcement of the First Case of COVID-19...

3. The announcement of the first case of Corona Virus (COVID-19) in Indonesia at a manufacturing company listed on the Stock Exchange, contains information that causes the capital market to react to market capitalization in terms of market value.

\section{Suggestions}

1. For management, to be careful with an event that occurs in Indonesia, because if the market capitalization is stable, the company will still be able to maintain its share price. Even if the market is affected by an event, it will not have a direct impact by drastically decreasing company value.

2. For investors, not to rush in making investment decisions without being easily affected by negative issues, but to first select and examine information obtained from trusted sites, in order to avoid capital loss and obtain capital gains from a events in Indonesia.

3. For further research and development, it is expected to use more objects, not just limited to one sector. Besides that, you can use other abnormal return calculation models such as a market model or a market adjusted model, which is combined with other variables as a comparison.

\section{Blibliography}

Akbar, E. P. (. (2019). Reaksi Pasar Modal Terhadap Pengumuman Kemenangan Presiden Joko Widodo Berdasarkan Keputusan KPU Pemilu Periode 2019-2024 (Studi pada Perusahaan BUMN yang Terdaftar di BEI). In Skripsi.

Andiani, Ni Wayan Sekar, and G. G. (2018). (2018). Pengaruh Volume Perdagangan Saham, Volatilitas Laba, Dividend Yield, Dan Ukuran Perusahaan Pada Volatilitas Harga Saham. E-Jurnal Akuntansi, 24(1), 21-48.

Deasy Lestary Kusnandar dan Vivi Indah Bintari. (2020). Perbandingan Abnormal Return Saham Sebelum dan Sesudah Perubahan Waktu Perdagangan Selama Pandemi Covid-19. Jurnal Pasar Modal Dan Bisnis, 2(2), 195-202.

Hanafi, M. M. (2008). Manajemen Keuangan (1st ed.). BPFE.

Hartono, J. (2003). Teori Portofollio dan Analisis Investasi (5th ed.). BPFE.

Inri B. Sambuari, Ivonne S. Saerang, J. B. M. (2020). Reaksi Pasar Modal Terhadap Peristiwa Virus Corona (Covid-19) pada Perusahaan Makanan dan Minuman yang Terdaftar di Bursa Efek Indonesia. Jurnal IImiah Manajemen Bisnis Dan Inovasi Universitas Sam Ratulangi (JMBI UNSRAT), 7(3), 407-415.

Niawaradila, B., Wiyono, G., \& Maulida, A. (2021). Pengaruh Frekuensi Perdagangan, 
Volume Perdagangan, dan Kapitalisasi Pasar Terhadap Return Saham Perusahaan Manufaktur yang Terdaftar Di BEI Periode 2016-2019. ECOBISMA (Jurnal Ekonomi, Bisnis, Dan Manajemen), 8(1), 122-138.

Putri, H. T. (2020). Covid 19 dan Harga Saham Perbankan di Indonesia. Eksis: Jurnal IImiah Ekonomi Dan Bisnis, 11(1), 6-9.

Rahyuda, et al. (2004). Modul Metodologi Penelitian. Universitas Udayana.

Ross, S. A., Westerfield, R., \& Jordan, B. D. (2003). Fundamentals of Corporate Finance. McGraw-Hill.

Shabib-ul-hasan, Syed, Sumair Farooq, and M. M. (2015). Stock Returns Indicators : Debt to Equity, Book to Market, Firm Size and Sales to Price. Of, Journal Poverty, Investment and Development, 16(81), 25-32.

Sugiyono. (2014). Metode Penelitian Bisnis. Alfabeta.

Taslim Ahmad, \& A. W. (2016). Pengaruh Frekuensi Perdagangan Saham, Kapitalisasi Pasar Dan Jumlah Hari Perdagangan Terhadap Return Saham. Management Analysis Journal, 5(1), 1-6. 